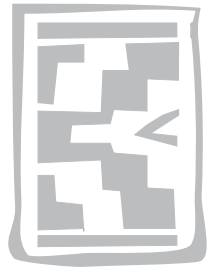

\title{
Study of the genetic heterogeneity of SAT-2 foot-and-mouth disease virus in sub-Saharan Africa with specific focus on East Africa
}

\author{
M. SAHLE ${ }^{1,2 \#, ~ R . M . ~ D W A R K A ~}{ }^{1}$, E.H. VENTER ${ }^{2}$ and W. VOSLOO ${ }^{1,2 *}$
}

\begin{abstract}
SAHLE, M., DWARKA, R.M., VENTER, E.H. \& VOSLOO, W. 2007. Study of the genetic heterogeneity of SAT-2 foot-and-mouth disease virus in sub-Saharan Africa with specific focus on East Africa. Onderstepoort Journal of Veterinary Research, 74:289-299

The epidemiology of serotype SAT-2 foot-and-mouth disease was investigated in sub-Saharan Africa by phylogenetic analysis using the 1D gene encoding the major antigenic determinant. Fourteen genotypes were identified of which three are novel and belong to East Africa, bringing the total number of genotypes for that region to eight. The genotypes clustered into three lineages that demonstrated surprising links between East, southern and south-western Africa. One lineage was unique to West Africa. These results established numerous incursions across country borders in East Africa and long term conservation of sequences for periods up to 41 years. Ethiopia, Kenya and Uganda have all experienced outbreaks from more than one unrelated strain, demonstrating the potential for new introductions. The amount of variation observed within this serotype nearly equalled that which was found between serotypes; this has severe implications for disease control using vaccination.

Keywords: 1D gene, East Africa, foot-and-mouth disease, phylogenetic study, SAT-2, sub-Saharan Africa
\end{abstract}

\section{INTRODUCTION}

There are seven immunologically distinct serotypes of foot-and-mouth disease (FMD) virus with different geographical distributions. The South African Territories (SAT) serotypes of FMD virus are prevalent in sub-Saharan Africa where outbreaks attributed to them have been recorded in many countries in East, West and southern Africa (Vosloo, Bastos,

* Author to whom correspondence is to be directed. E-mail: vosloow@arc.agric.za

1 Exotic Diseases Division, ARC-Onderstepoort Veterinary Institute, Private Bag X05, Onderstepoort, 0110 South Africa

2 Department of Veterinary Tropical Diseases, Faculty of Veterinary Science, University of Pretoria, Private Bag X04, Onderstepoort, 0110, South Africa

\# Present address: National Animal Health Research Centre, Ethiopian Agricultural Research Organization, P.O. Box 04, Sebeta, Ethiopia

Accepted for publication 7 May 2007-Editor
Sangare, Hargreaves \& Thomson 2002a). The SAT serotypes have been shown to be endemic to most African buffalo (Syncerus caffer) populations in southern Africa and, although not studied in such detail elsewhere, evidence suggests that buffaloes in East Africa are also persistently infected with SAT-1, SAT-2 and SAT-3 (Hedger, Forman \& Woodford 1973; Thomson \& Bastos 2004; Vosloo \& Thomson 2004). Although these animals generally do not show clinical disease, they excrete virus throughout the acute phase of the disease (Gainaru, Thomson, Bengis, Esterhuysen, Bruce \& Pini 1986) during which time they can infect other susceptible species. This is followed by a persistent infection where virus can only be found in the oro-pharyngeal region and, for buffaloes in particular, this period has been shown to be up to 5 years in a single animal (Condy, Hedger, Hamblin \& Barnett 1985). Circumstantial as well as experimental evidence have pointed to persistently infected buffaloes precipitating disease 
when in close contact with other susceptible species (Dawe, Flanagan, Madekurozwa, Sorensen, Anderson, Foggin, Ferris \& Knowles 1994a; Dawe, Sorenson, Ferris, Barnett, Armstrong \& Knowles 1994b; Vosloo, Bastos, Kirkbride, Esterhuysen, Janse van Rensburg, Bengis, Keet \& Thomson 1996; Bastos, Boshoff, Keet, Bengis \& Thomson 2000; Vosloo, Bastos \& Boshoff 2006) and new variants of virus being generated that could have severe implications on disease control reliant on the use of vaccines (Vosloo et al. 1996). Previous studies focusing mainly on buffalo isolates have indeed demonstrated large numbers of FMD virus variants present within specific geographic regions and in only a few cases could the transmission of virus from carrier buffaloes to susceptible livestock and wildlife be verified by phylogenetic analysis (Dawe et al. 1994a; Bastos et al. 2000; Vosloo, Boshoff, Dwarka \& Bastos 2002b; Vosloo et al. 2006). Other wild ungulates do not become long term carriers of FMD virus, but can spread the disease during acute infection (Hedger, Condy \& Golding 1972; Hedger 1981; Thomson, Bengis \& Brown 2001; Thomson, Vosloo \& Bastos 2003).

The causative virus, FMD virus, is one of two members of the Aphthovirus genus belonging to the Picornaviridae family. The single stranded RNA genome is 8500 nucleotides in length and encodes a single open reading frame. The viral RNA dependant RNA polymerase lacks proof reading ability which leads to significant nucleotide changes during each round of viral replication (Sobrino, Dávila, Ortin \& Domingo 1983). The rate of change for RNA viruses ranges between $10^{-1}$ and $10^{-4}$ substitutions per nucleotide per year (reviewed in Domingo, Baranowski, Escarmis \& Sobrino 2002) while rates in excess of $10^{-2}$ substitutions per nucleotide per year within the VP1-VP3 coding region have been found during an outbreak of FMD virus (Sobrino, Palma, Beck, Dávila, De la Torre, Negro, Villanueva, Ortin \& Domingo 1986; Villaverde, Martinez-Salas \& Domingo 1988) with the estimation that clones from a single isolate differ in approximately $0.6-2$ genomic positions, contemporary isolates in 2-20 positions and different isolates from a single outbreak differ in 50-100 genomic positions (reviewed in Domingo, Escarmis, Martinez, Martinez-Salas \& Mateu 1992; Sobrino, Saiz, Jimenez-Clavero, Nunez, Rosas, Baranowski \& Ley 2001).

The best method to date to differentiate between FMD virus isolates has been the determination of the RNA sequence encoding the VP1 protein which contains the major antigenic determinants of the vi- rus (Beck \& Strohmaier 1987; Samuel, Knowles \& Kitching 1988). Despite the success in elucidating the epidemiology of the disease, sequence data do not predict with accuracy the influence on the antigenicity of the virus and therefore cannot at present be used in isolation to recommend vaccine strains. This is of particular interest in regions where vaccination is used to control and eradicate the disease, as it is imperative that vaccines be used that are antigenically closely related to viruses circulating in the field (Hunter 1998).

Of the SAT serotypes most outbreaks in domestic animals have been recorded for SAT-2 (Thomson \& Bastos 2004) giving credence to the fact that SAT-2 may be most efficient in crossing species barriers (Bastos 2001). This serotype has also spread into the Middle East on at least two occasions (Ferris \& Donaldson 1992; Bastos, Haydon, Sangare, Boshoff, Edrich \& Thomson 2003b). In contrast, most buffaloes first become infected with SAT-1, followed by SAT-2 and lastly by SAT-3 as determined by serological responses in young buffaloes in the Kruger National Park (KNP), South Africa (Thomson \& Bastos 2004). The genetic diversity of SAT-2 FMD isolates has been published previously for African countries with specific focus on southern Africa (Vosloo, Knowles \& Thomson 1992; Vosloo, Kirkbride, Bengis, Keet \& Thomson 1995; Bastos et al. 2003b) with limited data on isolates from East Africa. The present study was carried out to determine the genetic variability of the SAT-2 FMD isolates in East Africa and to elucidate their epidemiology on a subcontinental basis.

\section{MATERIALS AND METHODS}

\section{Viruses included in this study}

A total of 41 SAT-2 FMD virus isolates from Ethiopia, Sudan, Kenya, Uganda, Tanzania and Eritrea isolated between 1975 and 2000 were supplied by the World Reference Laboratory (WRL) for FMD at the Institute for Animal Health, Pirbright (United Kingdom). These isolates were propagated once on IBRS-2 cells before further processing.

\section{Nucleic acid isolation and RT-PCR amplification}

Total RNA was extracted from cell culture supernatant using a guanidium thiocyanate-silica method (Boom, Sol, Salimans, Jansen, Wertheim-van Dillen \& Van der Noordaa 1990). The RNA viral template was reverse transcribed using AMV reverse transcrip- 
tase (Promega) with antisense primer (P1) of Beck \& Strohmaier (1987) and DNA amplification has been described previously (Bastos 1998). The P1 primer complementary to the conserved $2 \mathrm{~A} / \mathrm{B}$ junction site and the forward primer binding within $1 C$ (VP3) termed VP3AB (5'-CACTGCTACCACTCRG AGTG-3') (Bastos 1998), were used to amplify an approximately $880 \mathrm{bp}$ fragment.

\section{DNA purification and cycle sequencing}

The PCR amplicon was excised from a $1.5 \%$ agarose gel and purified using the Qia Quick Gel Extraction Kit (Qiagen). Purified PCR products were sequenced using the Big Dye ${ }^{\circledR}$ version 3.0 Cycle Sequencing kit and the $\mathrm{ABI}$ Prism 310 Genetic Analyzer (Applied Biosystems). Two sequencing reactions were performed per isolate using identical upstream and downstream primers as in the PCR.

\section{Phylogenetic analysis}

The DAPSA program (Harley 2001) was used to align generated nucleotide sequences to data previously published for 26 isolates bringing the total number of isolates to 67 from 20 countries (Table 1). A homologous region of $648 \mathrm{bp}$ corresponding to the complete VP1 encoding gene and 6 nucleotides of the $2 \mathrm{~A}$ region was used for phylogenetic analysis. Phylogenetic reconstructions [neighbour joining (NJ) and minimum evolution (ME)] were carried out using methods of analysis included in MEGA version 2.0 (Kumar, Tamura, Jakobsen \& Nei 2001), with $\mathrm{p}$-distance, pair-wise deletions of gaps and confidence levels assessed by 1000 bootstrap replications. A gamma shape parameter of 0.9059 as determined in Model Test (Posada \& Crandall 1998) was used to construct the minimum evolution tree. Parsimony and UPGMA analysis were performed using MEGA version 2.0. Average pair-wise comparisons were conducted to estimate divergence within and between lineages and genotypes. A variability plot of sequences of the 1D gene of all virus isolates included in this study was determined using MEGA version 1.02 (Kumar, Tamura \& Nei 1993) with numbers of variable sites in overlapping windows of 10 and $>70 \%$ variation taken as an indication of hypervariability.

\section{RESULTS}

\section{Phylogenetic analysis}

Complete 1D gene sequences (648 bp) were used to determine phylogenetic relationships between the
67 SAT-2 isolates from sub-Saharan Africa and one isolate that had caused outbreaks in Saudi Arabia during 2000 (Table 1). NJ, UPGMA, ME and parsimony methods produced trees with similar topology (results not shown) indicating that the recovered phylogeny is a good estimate and reliable. Only the ME tree is shown (Fig. 1). The ME tree revealed three lineages which are summarized below and were broadly geographically linked, with lineage I consisting of isolates from East Africa, Angola, the Democratic Republic of Congo (DRC; Zaire) and Saudi Arabia, lineage II containing isolates from West Africa, while lineage III encompassed southern and East Africa.

\section{Lineage I}

Genotype G (Eritrea 1998 and Saudi Arabia 2000), genotype H (Rwanda 2000), genotype I (Kenya and Uganda 1957-1998), genotype J (Uganda 1998 and DRC 1982), genotype K (Angola 1974), genotype L (Uganda 1975-1976), genotype M (Sudan 1977), and genotype N (Ethiopia 1991)

\section{Lineage II}

Genotype E (Ghana, Nigeria and Senegal 19751991) and genotype F (Gambia and Senegal 19791983)

\section{Lineage III}

Genotype A (South Africa 1983-1995), genotype B (Ethiopia, Burundi, Kenya, Tanzania, Malawi 19751999), genotype C (Zambia and Botswana 19961998), genotype D (Zimbabwe and Botswana 19832000)

Previously, 11 genotypes were described for subSaharan Africa based on genetic distance and bootstrap support (Bastos et al. 2003b) and in this study the genotypes are assigned the same alphabetical letters to facilitate comparison. The phylogeny corresponded well to what was previously described for SAT-2 in sub-Saharan Africa (Bastos et al. 2003b, Sangare, Bastos, Venter \& Vosloo 2004). Three new genotypes were demonstrated in East Africa, viz. genotype $L$ that contained isolates from Uganda (1975-1976), genotype M with two isolates obtained in Sudan during 1977 and genotype N with a single isolate from Ethiopia made during 1991. In this study, the number of isolates from East Africa was increased compared to earlier studies and the previously described genotype $\mathrm{G}$ was shown to contain two more isolates obtained in Eritrea during 1998, genotype $\mathrm{H}$ remained the same with a single isolate 
Genetic heterogeneity of SAT-2 FMD virus in sub-Saharan Africa

TABLE 1 Summary of SAT-2 FMD viruses included in this study

\begin{tabular}{|c|c|c|c|c|}
\hline Virus designations & Country of origin & Year of sampling & Reference & Genbank accession no. \\
\hline KEN/3/57 & Kenya & 1957 & Unpublished & AJ251473 \\
\hline ANG/4/74\# & Angola & 1974 & Bastos et al. (2003b) & AF479417 \\
\hline $\mathrm{MAL} / 3 / 75^{\#}$ & Malawi & 1975 & Bastos et al. (2003b) & AF367099 \\
\hline $\mathrm{NIG} / 2 / 75$ & Nigeria & 1975 & Sangare et al. (2004) & AF367139 \\
\hline SEN/7/83 & Sénégal & 1983 & Sangare et al. (2004) & AF479414 \\
\hline SEN/5/75 & Sénégal & 1975 & Bastos et al. (2003b) & AF367099 \\
\hline TAN/1/75 & Tanzania & 1975 & This study & AY343970 \\
\hline UGA/51/75 & Uganda & 1975 & This study & AY343963 \\
\hline KEN/2/76 & Kenya & 1976 & This study & AY343940 \\
\hline UGA/3/76 & Uganda & 1976 & This study & AY343964 \\
\hline UGA/8/76 & Uganda & 1976 & This study & AY343965 \\
\hline SUD/6/77 & Sudan & 1977 & This study & AY343939 \\
\hline SUD/9/77 & Sudan & 1977 & This study & AY442014 \\
\hline GAM/8/79 & Gambia & 1979 & Sangare et al. (2004) & AF426093 \\
\hline GAM/9/79 & Gambia & 1979 & Sangare et al. (2004) & AF426078 \\
\hline $\mathrm{ZAI} / 1 / 82$ & Zaire & 1982 & Bastos et al. (2003b) & AF367100 \\
\hline PAL/5/83 & South Africa & 1983 & Bastos et al. (2003b) & AF367102 \\
\hline ZIM/7/83 & Zimbabwe & 1983 & Van Rensburg \& Nel (1999) & AF136607 \\
\hline $\mathrm{KEN} / 1 / 84$ & Kenya & 1984 & This study & AY344505 \\
\hline $\mathrm{KEN} / 2 / 84$ & Kenya & 1984 & This study & AY343941 \\
\hline $\mathrm{KEN} / 1 / 85$ & Kenya & 1985 & This study & AY343942 \\
\hline $\mathrm{KEN} / 1 / 86$ & Kenya & 1986 & This study & AY343943 \\
\hline TAN/1/86 & Tanzania & 1986 & This study & AY343971 \\
\hline $\mathrm{KEN} / 1 / 87$ & Kenya & 1987 & This study & AY343944 \\
\hline KEN/2/87 & Kenya & 1987 & This study & AY343945 \\
\hline $\mathrm{KEN} / 2 / 88$ & Kenya & 1988 & This study & AY343946 \\
\hline $\mathrm{KEN} / 1 / 89$ & Kenya & 1989 & This study & AY343947 \\
\hline ETH/1/90 & Ethiopia & 1990 & This study & AY343935 \\
\hline ETH/2/90 & Ethiopia & 1990 & This study & AY343936 \\
\hline $\mathrm{GHA} / 2 / 90$ & Ghana & 1990 & Sangare et al. (2004) & AF426081 \\
\hline $\mathrm{BUN} / 1 / 91$ & Burundi & 1991 & Bastos et al. (2003b) & AF367111 \\
\hline ETH/1/91 & Ethiopia & 1991 & This study & AY343937 \\
\hline $\mathrm{ETH} / 2 / 91$ & Ethiopia & 1991 & This study & AY343938 \\
\hline GHA/8/91 & Ghana & 1991 & Sangare et al. (2004) & AF426083 \\
\hline KEN/8/91 & Kenya & 1991 & This study & AY343949 \\
\hline KEN/28/91 & Kenya & 1991 & This study & AY343948 \\
\hline KEN/33/91 & Kenya & 1991 & This study & AY343950 \\
\hline UGA/3/91 & Uganda & 1991 & This study & AY343966 \\
\hline KEN/1/92 & Kenya & 1992 & This study & AY343953 \\
\hline $\mathrm{KEN} / 3 / 92$ & Kenya & 1992 & This study & AY343951 \\
\hline KEN/6/92 & Kenya & 1992 & This study & AY343952 \\
\hline KEN/1/94 & Kenya & 1994 & This study & AY343954 \\
\hline KEN/2/94 & Kenya & 1994 & This study & AY343955 \\
\hline KEN/3/95 & Kenya & 1995 & This study & AY343957 \\
\hline KEN/7/95 & Kenya & 1995 & This study & AY343956 \\
\hline $\mathrm{KNP} / 31 / 95^{*}$ & South Africa & 1995 & Bastos et al. (2003b) & AF367119 \\
\hline UGA/9/95 & Uganda & 1995 & This study & AY343967 \\
\hline KEN/1/96 & Kenya & 1996 & This study & AY343960 \\
\hline KEN/7/96 & Kenya & 1996 & This study & AY343959 \\
\hline KEN/11/96 & Kenya & 1996 & This study & AY343958 \\
\hline ZAM/10/96* & Zambia & 1996 & Bastos et al. (2003b) & AF367121 \\
\hline ВОТ/1/98* & Botswana & 1998 & Bastos et al. (2003b) & AF367122 \\
\hline BOT/31/98* & Botswana & 1998 & Bastos et al. (2003b) & AF367125 \\
\hline $\mathrm{ERI} / 1 / 98$ & Eritrea & 1998 & This study & AY343933 \\
\hline $\mathrm{ERI} / 4 / 98$ & Eritrea & 1998 & This study & AY343934 \\
\hline $\mathrm{ERI} / 12 / 98$ & Eritrea & 1998 & Bastos et al. (2003b) & AF367126 \\
\hline KEN/7A/98 & Kenya & 1998 & This study & AY343961 \\
\hline KEN/16/98 & Kenya & 1998 & This study & AY343962 \\
\hline UGA/19/98 & Uganda & 1998 & This study & AY343969 \\
\hline UGA/28/98 & Uganda & 1998 & This study & AY343968 \\
\hline ZIM/267/98* & Zimbabwe & 1998 & Bastos et al. (2003b) & AF367130 \\
\hline KEN/5/99 & Kenya & 1999 & Bastos et al. (2003b) & AF367131 \\
\hline KEN/7/99 & Kenya & 1999 & Bastos et al. (2003b) & AF367132 \\
\hline KEN/9/99 & Kenya & 1999 & Bastos et al. (2003b) & AF367135 \\
\hline RWA/1/00 & Rwanda & 2000 & Bastos et al. (2003b) & AF367134 \\
\hline SAU/6/00 & Saudi Arabia & 2000 & Bastos et al. (2003b) & AF367132 \\
\hline $\mathrm{ZIM} / 1 / 00^{*}$ & Zimbabwe & 2000 & Bastos et al. (2003b) & AF367136 \\
\hline
\end{tabular}

All unmarked isolates were obtained from cattle

* Buffalo isolate

\# Species of origin not known 
M. SAHLE et al.

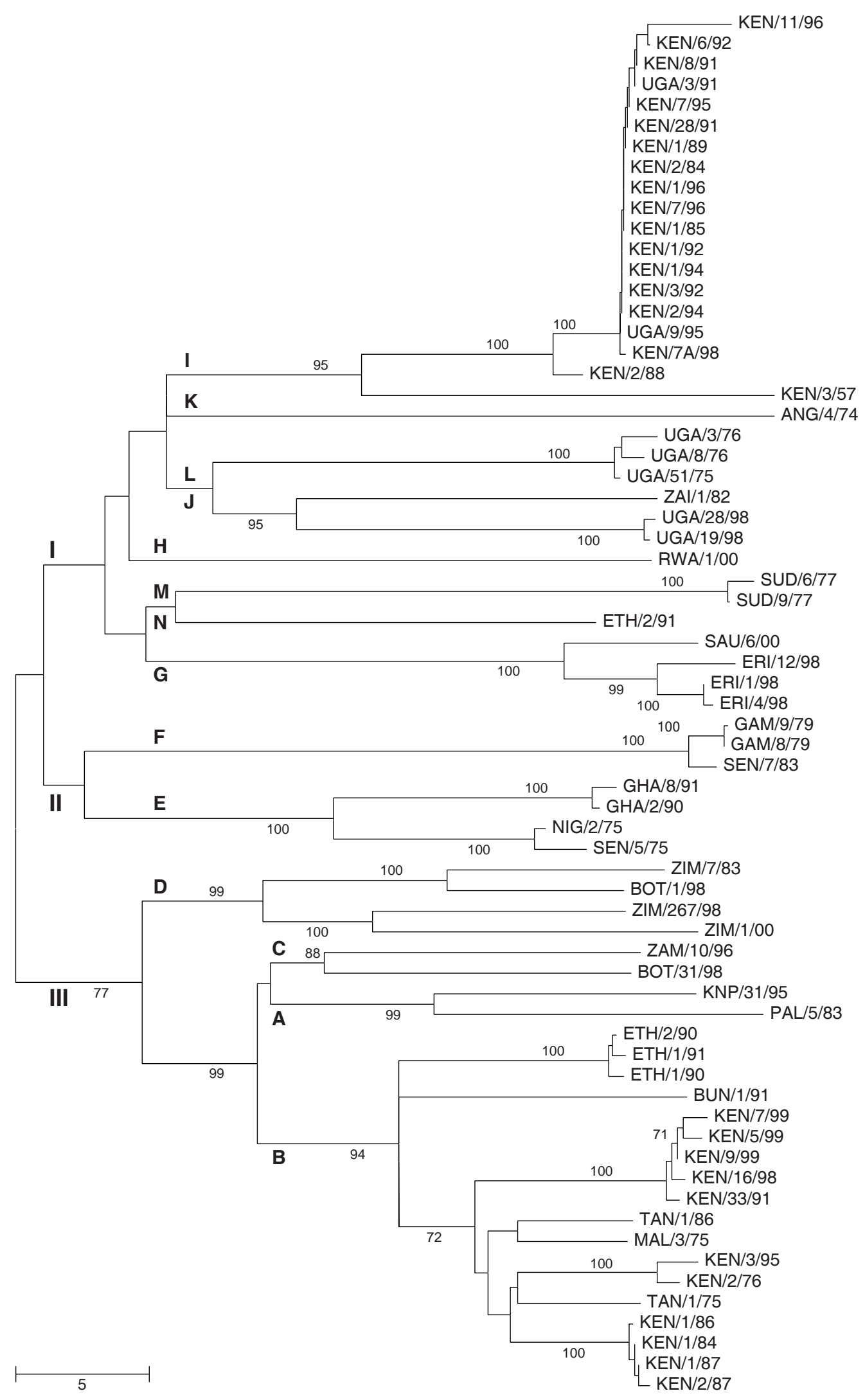

FIG. 1 Minimum evolution tree based on the 1D gene depicting genetic relationships of SAT-2 FMD isolates from sub-Saharan Africa. Bootstrap values were estimated based on 1000 replications. I-III depict the major lineages, while $\mathrm{A}-\mathrm{N}$ indicate genotypes 


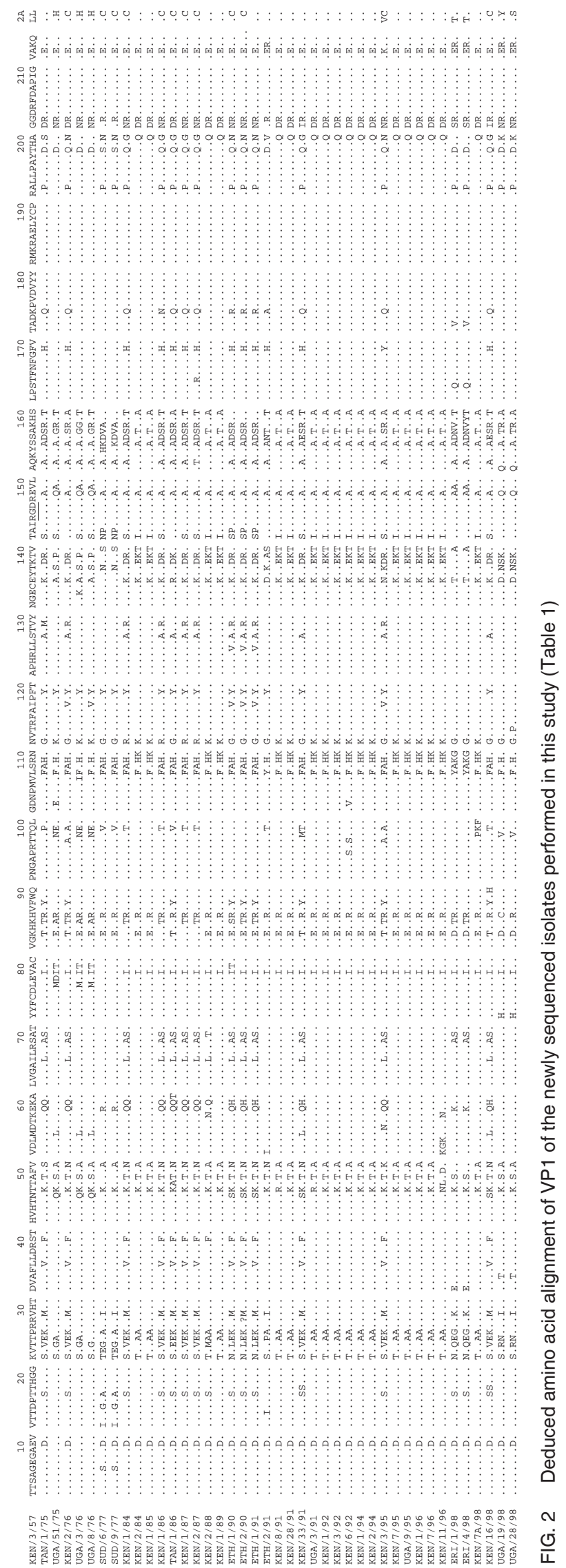


from Rwanda made during 2000 (RWA/1/00), while genotype I expanded with several more isolates from Kenya and Uganda in addition to demonstrating that this genotype had circulated for 41 years (1957-1998). Genotype J, that previously contained only one isolate from the DRC made during 1982 (ZAI/1/82), had two more isolates from Uganda 1998 (UGA/19/98 and UGA/28/98) and although these differed by $22 \%$ from the former, the cluster was supported by a bootstrap value of $95 \%$. The within genotype variation based on pair-wise comparisons was up to $26 \%$ while between genotype differences varied from approximately $30-44 \%$.

Closely related viruses, with sequence homology of $>94 \%$, caused a number of outbreaks between 1984 and 1998 in Kenya and Uganda, suggesting a direct epidemiological association between these outbreaks and possible long-term conservation (genotype I, lineage I; Fig. 1). A historical isolate made in 1957 in Kenya (KEN/3/57) clustered within this genotype with a high bootstrap support, but differed by $24 \%$ from the former cluster. In addition, three outbreaks caused by isolates from lineage III within genotype B had occurred in Kenya between 1976 and 1995 (KEN/2/76 and KEN/3/95), 1984-1987 (KEN/1/84, KEN1/86, KEN1/87, KEN2/87) and 1991-1999 (KEN/33/91, KEN/16/98, KEN/4/99, $\mathrm{KEN} / 5 / 99, \mathrm{KEN} / 7 / 99, \mathrm{KEN} / 9 / 99)$. While the isolates obtained within an outbreak differed by less than $2 \%$ from each other, the distances between these outbreak clusters were $9-13 \%$ and each cluster was supported by bootstrap of $100 \%$. Outbreaks from Tanzania during 1975 (TAN/1/75) and 1986 (TAN/1/86) as well as from Malawi during 1975 (MAL/3/75) clustered within genotype $B$ and seemed to be related to the ongoing outbreaks in the eastern African region based on a bootstrap support of 99\% (Fig. 1).

Uganda suffered from unrelated outbreaks between 1975-1976 (genotype L; UGA/51/75, UGA/3/76, UGA/8/76) and 1998 (genotype J) bringing the total number of unrelated outbreaks to three, all from different genotypes. The introduction into Rwanda during 2000 was unrelated to any of these previous outbreaks in neighbouring countries. During 19901991 Ethiopia had at least two separate introductions, with one isolate clustering within genotype $\mathrm{N}$ $(E T H / 2 / 91$; lineage I) and ETH1/90, ETH/2/90 and $\mathrm{ETH} / 1 / 91$ clustering within genotype $B$, lineage III. A single isolate from Burundi, made in 1991 also grouped in genotype $B$, indicated that this genotype had been circulating in East and southern Africa for 24 years.

\section{Genetic variability and distribution of mutations}

The invariable sites over the 1D gene for all the isolates included in the study were 236/638 (37\%), with $56 \%$ (358/638) parsimoniously informative sites and 54 singletons. For the deduced amino acid sequences, the invariable sites were $42 \%(91 / 216)$, $43 \%(93 / 216)$ parsimoniously informative sites and 32 singletons occurred. Amino acid variability was plotted to determine whether mutations were randomly distributed or localized to specific regions of the VP1 gene. The result of the amino acid hypervariability plots of 67 isolates from Africa indicated the hyper-variable regions were located at amino acid positions 45-50, 107-111, 135-141 and 148160 (within the G-H loop) as well as 198-202, the $\mathrm{C}$-terminal part of the protein. A putative hyper-variable site was also identified at positions 21-28, which corresponds with a T-cell epitope identified on O Kaufbeuren (Collen, Dimarchi \& Doel 1991) and was also recognised as hyper-variable for SAT-1 (Sahle, Dwarka, Venter \& Vosloo 2007).

When comparing only the newly generated deduced amino acid sequences of the 48 East African isolates, the RGD cell attachment site of the virus at amino acid positions 144-146 within the G-H loop was completely conserved across all isolates (Fig. 2). The $C$ at the base of the 1D loop (position 134) was maintained as well as the $R$ at position +1 , the $I$ at position -1 and the $L$ at position +4 . Of the previously described neutralisation sites identified by monoclonal antibodies at positions $+2,+3$ and +10 and +12 (Crowther, Rowe \& Butcher 1993; Bastos et al. 2003b), only +3 was moderately conserved with three (V/A/L) options, while at positions +2 and +10 , five different amino acids occurred and at position +12 seven differences were found (Fig. 2). Previously Bastos et al. (2003b) found that for representative isolates from sub-Saharan Africa, but with few of them being from East Africa, the +2 and +3 sites showed moderate levels of variation, while the +10 and +12 sites showed high levels. For the East African isolates, only the +3 site showed moderate variation. The VP1/2A cleavage site contained predominantly amino acid sequences VP1(K/R)Q/ $2 \mathrm{~A}(\mathrm{~L} / \mathrm{T} / \mathrm{V})(\mathrm{L} / \mathrm{C} / \mathrm{H} / \mathrm{S} / \mathrm{Y})$ with the $\mathrm{Q}$ at the cleavage site conserved over all isolates.

\section{DISCUSSION}

Phylogenetic analysis has been of great benefit in determining possible origins of FMD outbreaks, interspecies transmission, tracing spread of virus over vast distances and ultimately to better understand 
the epidemiology of the disease in sub-Saharan Africa (Vosloo et al. 1992; Dawe et al. 1994a; Vosloo et al. 1995; Bastos et al. 2000; Bastos 2001; Bastos, Haydon, Forsberg, Knowles, Anderson, Bengis, Nel \& Thomson, 2001; Sangare, Bastos, Marquardt, Venter, Vosloo \& Thomson 2001; Bastos, Anderson, Bengis, Keet, Winterbach \& Thomson 2003a; Bastos et al. 2003b; Sangare, Bastos, Venter \& Vosloo 2003; Sahle, Venter, Dwarka \& Vosloo 2004; Sangare et al. 2004; Vosloo \& Thomson 2004; Vosloo et al. 2006). SAT-2 isolates from East Africa have not been studied in detail and compared to those obtained from other regions to better understand and assess the molecular epidemiology of SAT-2 in sub-Saharan Africa. The phylogeny has expanded with three new genotypes identified in East Africa, bringing the total number to eight belonging to two different lineages. The previously identified lineages (Bastos et al. 2003b; Sangare et al. 2004) could not be followed in this study, as the inclusion of more isolates has altered the structure of the phylogeny at that level, albeit not on genotype level. Only three lineages were assigned in this study that covered East Africa and south-western Africa, one consisting solely of West African isolates and the third from East and southern Africa.

These linkages between different geographical regions of the subcontinent demonstrate clearly the potential for FMD virus to disperse over considerable distances and emphasize the need to investigate the main factors which play a role in exchange of subtypes of the virus between countries and its spread within and between regions. Transboundary transmission of the disease due to animal movement is possible as a number of countries share common boundaries and animal trading across borders is common practice (Ndiritu 1984). Added to this, the population of susceptible hosts for FMD in East African countries is high [the cattle and sheep population were estimated to be 57.6 and 98.9 million, respectively (McDermott \& Arimi 2002)], and can easily maintain cycles of FMD epizootics. The livestock and the livestock production systems, illegal trading of animal and animal products as well as the presence of cloven-hoofed wild animals in the region favour the transmission of disease between neighbouring countries and could lead to endemic cycles. A study performed in West Africa indicated clearly that the role of sheep and goats in the epidemiology of FMD is not fully understood either due to a real low prevalence of disease or, more likely, because clinical disease is not apparent and the importance of these species is overlooked (Bronsvoort, Tanya, Kitching, Nfon, Haman \& Morgan 2003). In
Sudan it was shown that sheep and goats play an important role in the epidemiology based on serological studies following natural infection (Abu Elzein, Newman, Crowther, Barnett \& McGrane 1987). Cross-border transmission was aptly demonstrated where an outbreak in Saudi Arabia was shown to cluster with three isolates previously obtained from Eritrea which was possibly due to spread of virus to Saudi Arabia arising from trade in livestock between the two countries (Bastos et al. 2003b). Similarly rare incursions of SAT-1 into the Middle East have been recorded (Knowles \& Samuel 2003). Within a geographical region such as East Africa, cross border movement most probably leads to dissemination of disease between various countries sharing borders.

More surprising was the demonstration that isolates from Angola and DRC clustered with the East African lineage I which is supported by a high bootstrap value. However, due to the low numbers of isolates available from central and south-western Africa, it is not possible to determine whether these were accidental introductions over large distances, or whether there are indeed similar isolates circulating within this geographical region.

A total of 14 genotypes were identified in sub-Saharan Africa. Of these, six may be extinct $(E, F, K, L$, $\mathrm{M}$ and $\mathrm{N}$ ) as no isolates similar to those included in this study have been found since 1996. However, in endemic areas the disease is often not reported nor material submitted for further investigation, implying that the exact distribution and occurrence of serotypes is not known. Bronsvoort et al. (2003) found by using questionnaires that the prevalence may be up to $58 \%$ in specific regions of Mali but outbreaks are not reported to veterinary services. Investigations into more recent isolates may prove that these and new genotypes are currently circulating within subSaharan Africa.

East Africa demonstrates the most variation of all regions in sub-Saharan Africa with at least eight genotypes in two lineages consisting almost exclusively of cattle isolates, compared to southern Africa where three genotypes have been described (Bastos et al. 2003b), the latter consisting mostly of buffalo isolates. Previously, Bastos et al. (2003b) found that the highest rates of nucleotide substitution for SAT-2 groups were those that were recovered from cattle, while the lowest rates were recovered from wildlife. They speculated that these different rates could have been due to a higher number of cases during cattle outbreaks resulting in more virus replication and more opportunity for divergence although 
their study could not support this assumption statistically. From the data included in this study, it is clear that within East Africa at least, more variation is observed, giving credence to the fact that the disease is most probably maintained by livestock. Other factors cannot be excluded in generating this diversity. The role of buffaloes in these regions is largely unknown, and more studies into the presence of SAT serotype viruses in buffaloes in the area could provide an explanation. In addition, the role of other wildlife species is also not clear. In southern Africa and in the KNP in particular, it has been shown that impalas can play an important role in transmitting disease to other species (Vosloo et al. 2006). In addition to transboundary movement of livestock which could spread disease, introduction of strains due to vaccine cannot be excluded. The latter could explain the long term conservation of genotypes observed over extended time periods.

A number of East African countries have had separate incursions of disease belonging to different lineages and genotypes such as Kenya, Ethiopia and Uganda. These genetic differences lead to antigenic differences (Vosloo, Dwarka, Bastos, Esterhuysen, Sahle \& Sangare 2004) and have an important bearing on the use of vaccination to control the disease. Cross neutralisation studies have shown that even within a genotype of SAT-2, the antigenic relationships are sufficiently poor to warrant specific vaccines strains and there will probably be no protection between genotypes (Vosloo et al. 2004). Countries will have to consider the strains and genotypes included in vaccines to ensure that vaccination will be effective. These differences could also have a negative impact on diagnostic tests relying on antigenic relationships between viruses and should be considered when diagnoses are required. In contrast Tanzania, Rwanda and Eritrea had outbreaks caused by single genotypes, but this could be due to under representation, rather than a true reflection of the current status.

The seven serotypes of FMD virus cluster into lineages that differ by approximately $30-50 \%$ over the 1D gene (Knowles \& Samuel 2003). In this study it was observed that lineages differ by up to $44 \%$ from each other, nearly as much as was found for serotypes, indicating the high level of mutation found in SAT-2. A similar level of variation was observed for SAT-1 when isolates from over sub-Saharan Africa were investigated (Sahle et al. 2007). Knowles \& Samuel (2003) suggested that variation of up to $20 \%$ could be used for inclusion into a SAT topotype. However, it was found in this study that certain genotypes that corresponded to geographical locations (ie topotypes) had up to $26 \%$ within group variation (genotype $\mathrm{D}$ ) when pairwise comparisons were performed and it seems plausible that these cut-off levels should be redefined, especially for the SAT types.

The hyper-variable regions of the East African isolates compared to those identified for SAT-1 and SAT-2 with 135-141 and 148-160 corresponding to the $\beta \mathrm{G}-\beta \mathrm{H}$ loop (Bastos et al. 2001; Bastos et al. 2003b; Vosloo et al. 2006; Sahle et al. 2007). Sites $107-111$ correspond to the $\beta F-\beta G$ loop shown to be hyper-variable for SAT-1 and SAT-3 (Bastos 2001; Bastos et al. 2003a, b), while 45-50 correspond to the $\beta \mathrm{B}-\beta \mathrm{C}$ loop identified on O1 BFS (Acharaya, Fry, Stuart, Fox, Rowlands \& Brown 1989) and shown to be hyper-variable for SAT-1 (Vosloo et al. 2006; Sahle et al. 2007). This high level of variation around the immunologically important GH loop which also plays a role in cell receptor recognition (Logan, Abu-Ghazaleh, Blakemore, Curry, Jackson, King, Lea, Lewis, Newman \& Parry 1993) could have a severe impact on the efficacy of vaccines. As was demonstrated in previous studies investigating SAT-2, the arginine at position 148 was conserved in all isolates investigated. The role of this change from leucine (as in most other serotypes) to arginine is not clear as the leucine has been shown to stabilize alpha helix formation (France, Piatti, Newman, Toth, Gibbons \& Brown 1994).

This study adds to our understanding of the molecular epidemiology of SAT-2 FMD isolates in subSaharan Africa and demonstrates clearly that control of this disease should be seen as a regional priority due to the virus' ability to spread over vast distances. It also indicates that our understanding of the factors that lead to the generation of variants, disappearance and re-emergence of strains and regional patterns is inadequate and that more research is needed to ensure better prediction of disease emergence and effective control policies.

\section{ACKNOWLEDGEMENTS}

We thank N. Ferris of the Institute for Animal Health, Pirbright, UK for supplying the majority of virus isolates for this study. We are also very grateful to all technical staff of the Exotic Diseases Division of the Onderstepoort Veterinary Institute for their technical assistance. Particular thanks must be expressed to A.D.S. Bastos, K. Boshoff, H.G. O'Neill and F.F. Maree for valuable discussions. The work was supported by Intervet International. 


\section{REFERENCES}

ABU ELZEIN, E.M.E., NEWMAN, B.J., CROWTHER, J.R., BARNETT, I.T. \& MCGRANE, J.J. 1987. The prevalence of antibodies against foot-and-mouth disease in various species of Sudanese livestock following natural infection. Revue d'Élevage et de Médecine Vétérinaire des Pays Tropicaux, 10:712.

ACHARYA, R., FRY, E., STUART, D., FOX, G., ROWLANDS, D. \& BROWN, F. 1989. The three-dimensional structure of footand-mouth disease virus at $2.9 \AA$ resolution. Nature, 337: 709-716.

BASTOS, A.D.S. 1998. Detection and characterization of footand-mouth disease in sub-Sahara Africa. Onderstepoort Journal of Veterinary Research, 65:37-47.

BASTOS, A.D.S., BOSHOFF, C.I., KEET, D.F., BENGIS, R.G. \& THOMSON, G.R. 2000. Natural transmission of foot-andmouth disease virus between African buffalo (Syncerus caffer) and impala (Aepyceros melampus) in the Kruger National Park, South Africa. Epidemiology and Infection, 124:591598.

BASTOS. A.D.S. 2001. Molecular epidemiology and diagnosis of SAT-type of foot-and-mouth disease in southern Africa. Ph.D thesis, University of Pretoria.

BASTOS, A.D.S., HAYDON, D.T., FORSBERG, R., KNOWLES, N.J., ANDERSON, E.C., BENGIS, R.G., NEL, L.H. \& THOMSON, G.R. 2001. Genetic heterogeneity of SAT-1 type footand-mouth disease viruses in southern Africa. Archives of Virology, 146:1537-1551.

BASTOS, A.D., ANDERSON, E.C., BENGIS, R.G., KEET, D.F., WINTERBACH, H.K. \& THOMSON, G.R. 2003a. Molecular epidemiology of SAT 3-type foot-and-mouth disease. Virus Genes, 27:283-290.

BASTOS, A.D.S., HAYDON, D.T., SANGARE, O., BOSHOFF, C.I., EDRICH, J.L. \& THOMSON, G.R. 2003b. The implications of virus diversity within the SAT2 serotype for control of foot-and-mouth disease in sub-Saharan Africa. Journal of General Virology, 84:1595-1606.

BECK, E. \& STROHMAIER, K. 1987. Subtyping of European FMDV outbreak strains by nucleotide sequence determination. Journal of Virology, 61:1621-1629.

BOOM, R., SOL, C.J., SALIMANS, M.M.M., JANSEN, C.L., WERTHEIM-VAN DILLEN, P.M.E. \& VAN DER NOORDAA, J. 1990. Rapid and simple method for purification of nucleic acids. Journal of Clinical Microbiology, 28:495-503.

BRONSVOORT, B.M. DE C., TANYA, V.N., KITCHING, R.P., NFON, C., HAMAN, S.M. \& MORGAN, K.L. 2003. Foot-andmouth disease and livestock practices in the Adamawa province of Cameroon. Tropical Animal Health and Production, 35:491-507.

COLLEN, T., DIMARCHI, R. \& DOEL, T.R. 1991. A T cell epitope in VP1 of foot-and-mouth disease is immunodominant for vaccinated cattle. Journal of Immunology, 146:749-55.

CONDY, J.B., HEDGER, R.S., HAMBLIN, C. \& BARNETT, I.T.R. 1985. The duration of foot-and-mouth disease carrier state in African buffalo (i) In the individual animal and (ii) in a free-living herd. Comparative Immunology, Microbiology and Infectious Diseases, 8:259-265.

CROWTHER, J.R., ROWE, C.A. \& BUTCHER, R. 1993. Characterization of monoclonal antibodies against a type SAT 2 foot-and-mouth disease virus. Epidemiology and Infection, 111:391-406.

DAWE, P.S., FLANAGAN, F.O., MADEKUROZWA, R.L., SORENSEN, K.J., ANDERSON, E.C., FOGGIN, C.M., FERRIS, N.P.
\& KNOWLES, N.J. 1994a. Natural transmission of foot-andmouth disease from African buffalo (Syncerus caffer) to cattle in a wildlife area of Zimbabwe. Veterinary Record, 134: 230-232.

DAWE, P.S., SORENSON, K., FERRIS, N.P., BARNETT, I.T.R., ARMSTRONG, R.M. \& KNOWLES, N.J. 1994b. Experimental transmission of foot-and-mouth disease virus from carrier African buffalo (Syncerus caffer) to cattle in Zimbabwe. Veterinary Record, 134:211-215.

DOMINGO, E., ESCARMIS, C., MARTINEZ, M.A., MARTINEZSALAS, E. \& MATEU, M.G. 1992. Foot-and-mouth disease virus populations are quasispecies. Current Topics in Microbiology and Immunology, 176:33-34.

DOMINGO, E., BARANOWSKI, E., ESCARMIS, C. \& SOBRINO, F. 2002. Foot-and-mouth disease virus. Comparative Immunology, Microbiology and Infectious Diseases, 25:297-308.

FERRIS, N.P. \& DONALDSON, A.I. 1992. The World Reference Laboratory for foot-and-mouth disease: a review of thirtythree years of activity (1958-1991). Revue Scientific Technique Office International des Épizooties, 11:657-684.

FRANCE, L.L., PIATTI, P.G., NEWMAN, J.F.E., TOTH, I., GIBBONS, W.A. \& BROWN, F. 1994. Circular dichroism, molecular modelling, and serology indicate that the structural basis of antigenic variation in foot-and-mouth disease virus is $\alpha$ helix formation. Proceedings of the National Academy of Science USA, 91:8442-8446.

GAINARU, M.D., THOMSON, G.R., BENGIS, R.G., ESTERHUYSEN, J.J., BRUCE, W. \& PINI, A. 1986. Foot-and-mouth disease and the African buffalo (Syncerus caffer). II. Virus excretion and transmission during acute infection. Onderstepoort Journal of Veterinary Research, 53:75-85.

HARLEY, E.H. 2001. DAPSA, DNA and protein sequence analysis, version 4.91. Department of Chemical Pathology, University of Cape Town, South Africa.

HEDGER, R.S., CONDY, J.B. \& GOLDING, S.M. 1972. Infection of some species of African wildlife with foot-and-mouth disease virus. Journal of Comparative Pathology, 82:455-461.

HEDGER, R.S., FORMAN, A.J. \& WOODFORD, M.H. 1973. Foot-and-mouth disease in East African buffalo. Bulletin of Epizootic Diseases of Africa, 21:99-101.

HEDGER, R.S. 1981. Foot-and-mouth disease, in Infectious Diseases of wild mammals, $2^{\text {nd }}$ ed., edited by J.W. Davis, L.H. Karstad \& D.O. Trainer. Aimes: lowa State University Press.

HUNTER, P. 1998. Vaccination as a means of control of footand-mouth disease in sub-Saharan Africa. Vaccine, 16:261264.

KNOWLES, N.J. \& SAMUEL, A.R. 2003. Molecular epidemiology of foot-and-mouth disease virus. Virus Research, 91:65-80.

KUMAR, S., TAMURA, K. \& NEI, M. 1993. Molecular evolutionary genetics analysis version 1.0. The Pennsylvania State University, USA.

KUMAR, S., TAMURA, K., JAKOBSEN, I.B. \& NEI, M. 2001. MEGA 2: Molecular evolutionary genetics analysis software. Arizona State University, Tempe, Arizona, USA.

LOGAN, D., ABU-GHAZALEH, R., BLAKEMORE, W., CURRY, S., JACKSON, T., KING, A., LEA, S., LEWIS, R., NEWMAN, J. \& PARRY, N. 1993. Structure of a major immunogenic site on foot-and-mouth disease virus. Nature, 362:566-568.

MCDERMOTT, J.J. \& ARIMI, S.M. 2002. Brucellosis in subSaharan Africa: epidemiology, control and impact. Veterinary Microbiology, 90:111-134. 
NDIRITU, C.G. 1984. Foot-and-mouth disease virus antigenic variation and its implication on vaccine, Kenya. Kenyan Veterinary, 8:14-19.

POSADA, D. \& CRANDALL, K.A. 1998. Modeltest: testing the model of DNA substitution. Bioinformatics, 14:817-818.

SAHLE, M., DWARKA, R.M., VENTER, E.H. \& VOSLOO, W. 2007. Comparison of SAT-1 foot-and-mouth disease virus isolates obtained from East Africa between 1971 and 2000 with viruses from the rest of sub-Saharan Africa. Archives of Virology, 152:797-804.

SAHLE, M., VENTER, E.H., DWARKA, R.M. \& VOSLOO, W. 2004. Molecular epidemiology of serotype $O$ foot-and-mouth disease viruses isolated from cattle in Ethiopia between 1977-2001. Onderstepoort Journal of Veterinary Research, 71:129-138.

SAMUEL, A.R., KNOWLES, N.J. \& KITCHING, R.P. 1988. Serological and biochemical analysis of some recent type A footand-mouth disease virus isolates from the Middle East. Epidemiology and Infection, 101:577-90.

SANGARE, O., BASTOS, A.D.S., MARQUARDT, O., VENTER, E.H., VOSLOO, W. \& THOMSON, G.R. 2001. Molecular epidemiology of serotype $O$ foot-and-mouth disease virus with emphasis on West and South Africa. Virus Genes, 22:343349.

SANGARE, O., BASTOS, A.D.S., VENTER, E.H. \& VOSLOO, W. 2003. Retrospective genetic analysis of SAT-1 type foot-andmouth disease outbreaks in West Africa (1975-1981). Veterinary Microbiology, 93:279-289.

SANGARE, O., BASTOS, A.D.S., VENTER, E.H. \& VOSLOO, W. 2004. A first molecular epidemiological study of SAT-2 type foot-and-mouth disease viruses in West Africa. Epidemiology and Infection, 132:525-532.

SOBRINO, F., DÁVILA, M., ORTIN, J. \& DOMINGO, E. 1983. Multiple genetic variants arise in the course of replication of foot-and-mouth disease virus in cell culture. Virology, 128: 310-318.

SOBRINO, F., PALMA, E.L., BECK, E., DAVILA, M., DE LA TORRE, J.C., NEGRO, P., VILLANUEVA, N., ORTIN, J. \& DOMINGO, E. 1986. Fixation of mutations in the viral genome during an outbreak of foot-and-mouth disease: heterogeneity and rate variations. Gene, 50:149-59.

SOBRINO, F., SAIZ, M., JIMENEZ-CLAVERO, M.A., NUNEZ, J.I., ROSAS, M.F., BARANOWSKI, E. \& LEY, V. 2001. Footand-mouth disease virus: a long known virus, but a current threat. Veterinary Research, 32:1-30.

THOMSON, G.R., BENGIS, R.G. \& BROWN, CC. 2001. Picornaviruses, in Infectious diseases of wild mammals, $3^{\text {rd }}$ ed., edited by E.S. Williams \& I.K. Barker. Ames: lowa University Press.

THOMSON, G.R., VOSLOO, W. \& BASTOS, A.D.S. 2003. Footand-mouth disease in wildlife. Virus Research, 91:145-61.

THOMSON, G.R. \& BASTOS, A.D.S. 2004. Foot-and-mouth disease, in Infectious diseases of livestock, $2^{\text {nd }}$ ed., edited by
J.A.W. Coetzer \& R.C. Tustin. Cape Town: Oxford University Press, Southern Africa.

VAN RENSBURG, H.G. \& NEL, L.H. 1999. Characterization of the structural-protein-coding region of SAT-2 type foot-andmouth disease virus. Virus Genes, 19:229-233.

VILLAVERDE, A., MARTINEZ-SALAS, E. \& DOMINGO, E. 1988. 3D gene of foot-and-mouth disease virus. Conservation by convergence of average sequences. Journal of Molecular Biology, 204:771-6.

VOSLOO, W., KNOWLES, N.J. \& THOMSON, G.R. 1992. Genetic relationships between southern Africa SAT 2 isolates of footand-mouth disease virus. Epidemiology and Infection, 109: 547-558.

VOSLOO, W., KIRKBRIDE, E., BENGIS, R.G., KEET, D.F. \& THOMSON, G.R. 1995. Genome variation in the SAT types of foot-and-mouth disease prevalent in buffalo (Syncerus caffer) in the Kruger National Park and other regions of southern Africa. 1986-1993. Epidemiology and Infection, 114:203218.

VOSLOO, W., BASTOS, A.D.S., KIRKBRIDE, E., ESTERHUYSEN, J.J., JANSE VAN RENSBURG. D., BENGIS, R.G., KEET, D.F. \& THOMSON, G.R. 1996. Persistent infection of African buffalo (Syncerus caffer) with SAT type foot-andmouth disease viruses: rate of fixation of mutations, antigenic change and interspecies transmission. Journal of General Virology, 77:1457-1467.

VOSLOO, W., BASTOS, A.D.S., SANGARE, O., HARGREAVES, S.K. \& THOMSON, G.R. 2002a. Review of the status and control of foot-and-mouth disease in sub-Saharan Africa. Revue Scientific Technique Office International des Épizooties, 21:437-449.

VOSLOO, W., BOSHOFF, K., DWARKA, R. \& BASTOS, A. $2002 \mathrm{~b}$. The possible role that buffalo played in the recent outbreaks of foot-and-mouth disease in South Africa. Annals of the New York Academy of Science, 969:187-190.

VOSLOO, W., DWARKA, R.M., BASTOS, A.D.S., ESTERHUYSEN, J.J., SAHLE, M. \& SANGARE, O. 2004. Molecular epidemiological studies of foot-and-mouth disease virus in subSaharan Africa indicate the presence of large numbers of topotypes: implications for local and international control. Report of the European Commission for the control of footand-mouth disease, session of the Research Group of the Standing Technical Committee, Food and Agriculture Organisation of the United Nations, Chania, Crete, Greece, 11-15 October 2004.

VOSLOO, W. \& THOMSON, G.R. 2004. Natural habitats in which foot-and-mouth disease viruses are maintained, in Foot-andmouth disease: current perspectives, edited by E. Domingo \& F. Sobrino. Great Britain, Horizon Bioscience.

VOSLOO, W., BASTOS, A.D.S. \& BOSHOFF, C.I. 2006. Retrospective genetic analysis of SAT-1 type foot-and-mouth disease outbreaks in southern Africa. Archives of Virology, 151: 285-289. 